\title{
Preliminary and Biochemical Characterization of Bacterial Strains Isolated from Ramie Cane Soils
}

\author{
Darsi Phebe Sarah Koti Ratnam*1, Davala Simon² \\ ${ }^{1}$ Department of Botany \& Microbiology, Andhra Christian College, Guntur, Andhra \\ Pradesh, India \\ ${ }^{2}$ Department of Botany and Microbiology, Acharya Nagarjuna University, Guntur, Andhra \\ Pradesh, India \\ *Corresponding author email : phebesarah63@gmail.com
}

\begin{abstract}
For the present study a total of 18 bacterial isolates were isolated from Ramie canes soils. Preliminary characteristics like colony characteristics and substrate concentrations were studied for the microorganisms. Physicochemical factors affecting the bacterial growth. The three seasons winter, summer and rainy seasons were also affected the growth of the bacteria. Various substrates like starch peptone, xylan peptone, Glycerol, Aspargine, glucose nitrate agar, carboxymethyl cellulose agar and pectin peptone agar media were studied. Maximum colony growth was recorded in pectin peptone agar media. Cream white, orange, red, yellow, lemon yellow and watery white colonies were recorded. The size of the bacterial strains was recorded in 1-55 $\mathrm{mm}$ in diameter. All the strains were entire lobed, convex having smooth and rough surface. of the 18 strains 11 were gram positive rods and the remaining strains were negative rods. Among the 18 strains, we were selected six strains for further studies like effect of seasons on growth and amino acid infilteration of bacteria. Maximum growth was recorded in winter season with 85.0 colony count in the presence of CCLS strain. There are 10 amino acids were introduced into the bacteria, with maximum growth was WCES bacterial strain. The results of this study reveal that the soil microflora associated with the ramie cane soils. These bacterial strains were used in the process of decortication and degumming.
\end{abstract}

Keywords : Ramie Canes, Isolation, Bacteria

\section{INTRODUCTION}

Ramie is a perennial herbaceous plant of the Utricaceae family, that provides a fibre of excellent quality. Harvest time and crop affected the agronomic performance and fibre properties of ramie. Ramie showed a good adaptability to the pedoclimatic conditions of the Mediterranean region, providing new perspectives for arable farming system. The crop persisted for upto 13 years giving stable off take of bast fibre. The main change in the cell wall composition during the development concerns lignin and cellulose than hemicelluloses material.

Ramie has been grown in China for many centuries, and farmers in ancient China are known to have used the fiber to weave clothing. It may have been used in cloths for wrapping mummies in Egypt. Though ramie and flax are difficult to distinguish in ancient 
cloth, ramie's resistance to bacteria and mildew would make it appropriate for mummy wrapping [1]. Ramie was used to produce an open-weave fabric called mechera, used for shirts and dressing gowns suitable for warm climates. The French painter Raoul Dufy designed in the early 20th century patterns for prints on mechera used by the French shirtmaker Charvet [2].

Brazil began production in the late 1930s with production peaking in 1971. Since then, production has steadily declined as a result of competition with alternative crops, such as soybeans and the important synthetic fibers [3].

Ramie (Boehmeria nivea L.) is one of the oldest crops in China and the second most important fiber crop in terms of area sown. Ramie root and leaf have therapeutic use in TCM. Thirteen genes that belong to the cellulose synthase gene family (four), the expansin gene family (three), and the xyloglucan [4]. Ramie is used to make such products as industrial sewing thread, packing materials, fishing nets, and filter cloths [5]. It is also made into fabrics for household furnishings (upholstery, canvas) and clothing, frequently in blends with other textile fibers (for instance when used in a mixture with wool, shrinkage is reported to be greatly reduced when compared with pure wool.) Shorter fibbers and waste are used in paper manufacture. Ramie ribbon is used in fine bookbinding as a substitute for traditional linen tape [6].

Hence this work related to isolate the bacterial colonies from ramie cane soils. Various bacteria and fungi were present in the ramie cane soils. Therefore the present study mainly focussed on bacterial preliminary characterization, biochemical characterization and their optimization studies. These ramie canes were used as baits for obtaining effective decorticating and degumming microbes.

\section{METHODS AND MATERIAL}

\section{Isolation of bacteria}

Ramie canes were cut into small pieces with appropriate lengths (2"- 4") and were surface sterilized. The pieces were buried at a depth of 3 " in the soil of coconut in holes bored with sterilized troves. The pieces were removed after desired interval and washed in gentle stream of water to remove excess soil. The canes were then placed on Glucosenitrate Agar, cellulose peptone Agar and incubated 96 hours and at $35^{\circ} \mathrm{C}$ temperatures. After incubation the pure colonies were picked and maintained for further studies. 18 species of bacteria were isolated from soil surrounding Ramie canes [7].

\section{Source of cultures}

A collection of bacteria isolated from hot water spring environments is available in Botany research laboratory. Some of these bacteria were used in this study cultures of Agrobacterium and corynebacterium were obtained from national collection of industrial microorganisms, national chemical lab pune. In addition the cultures isolated through ramie baits were used in various experiments [8].

\section{Culture incubation and colony morphology}

Cultures were incubated at 26 to $28^{\circ} \mathrm{C}$ in the laboratory and variation in temperature was recorded during the entire year study. In all the experiments the cultures were incubated for 8 days and the colony characteristics were studied. The colony characters like incubation period, grams test, margin, elevation and colour of the colonies were observed [9].

\section{Substrates}

Different substrates were used in the study for the maximum bacterial growth. The substrates were starch peptone, xylan peptone, Glycerol, Aspargine, glucose nitrate agar, carboxymethyl cellulose agar 
and pectin peptone agar media used for the bacterial growth [10].

\section{Amino acid infilteration}

There are 10 amino acids were used in the study for the bacterial strains isolated in the ramie canes. These amino acids were used $10 \mathrm{mg} /$ litre was used. Major effects and the results were recorded. Infilteration was measured by the use of spectrophotometer at 480 $\mathrm{nm}[11]$.

\section{RESULTS AND DISCUSSION}

From the present study reveals that, a total bacterium of 18 bacterial strains were isolated from ramie canes.
Soil samples were air dried and by using 3 to 4 serial dilutions for the successful isolation of bacteria. The pure colonies were separated and maintained in slants. Freshly prepared pure colonies were spot inoculated on the plates. These plates were incubated for 72 hours on room temperature. Colony growth and morphology was observed in (Table-1). Among the 18 strains 4 strains LYCES-13, CCES-11, WCESP2 and WCES-5 showed the white colour colonies. Maximum no of strains showed the cream in colour. The two strains CCERD-10 and CCERD-12 showed orange colour colonies.

Table -1. Colony Characteristics

\begin{tabular}{|c|c|c|c|c|c|c|}
\hline Isolate no. & Colour of the colony & Size $(\mathbf{m m})$ & Margin & Elevation & Surface & Grams test \\
\hline CSIR-1 & Cream & 20 & Lobed & Flat & Rough & Positive \\
\hline LYCES-13 & White & 1 & Entire & Convex & Smooth & Positive \\
\hline CCES-11 & White & 3 & Lobed & Convex & Smooth & Positive \\
\hline WCESP-2 & White & 5 & Wavy & Flat & Rough & Positive \\
\hline WCES-5 & White & 4 & Wavy & Convex & Smooth & Negative \\
\hline WCRS & Cream & 4 & Lobed & Convex & Smooth & Positive \\
\hline WSIR & Cream & 4 & Entire & Convex & Smooth & Negative \\
\hline CCWSD & Cream & 3 & Entire & Flat & Smooth & Negative \\
\hline CCLS-18 & Cream & 2 & Entire & Convex & Smooth & Negative \\
\hline Pseudomonas & Cream & 5 & Entire & Flat & Smooth & Positive \\
\hline OCESC-16 & Cream & 4 & Entire & Flat & Smooth & Positive \\
\hline WCWPS-3 & Cream & 5 & Entire & Convex & Smooth & Positive \\
\hline WCLS & Lemon yellow & 2 & Entire & Convex & Smooth & Negative \\
\hline WWCES-19 & Yellow & 3 & Lobed & Convex & Smooth & Negative \\
\hline CCESD-12 & Orange & 5 & Entire & Flat & Smooth & Negative \\
\hline CCERD-10 & Orange & 3 & Entire & Convex & Smooth & Positive \\
\hline RCES-17 & Cream & 2 & Lobed & Convex & Smooth & Negative \\
\hline CCRS & Watery white & 3 & Entire & Low & Smooth & Positive \\
& & & & Convex & & \\
\hline
\end{tabular}




\section{Effect of substrates on isolation of bacteria}

The bacteria from ramie canes grew well in the substrates like starch, peptone, xylan peptone, glycerol Aspargine, Glucose nitrate agar, CMC and peptone agar. Among the 18 bacteria the strain CSIR-
1, WCES-5 and CCRS showed the maximum growth by utilising the substrates. The three strains Pseudomonas, CCWSD and WCCS showed minimum growth on by using these substrates. The two strains CCESD-12 and RCES-17 showed negative growth by means of there was no growth (Table-2).

Table -2. Effect of substrate on isolation of bacteria

\begin{tabular}{|l|l|l|l|l|l|l|}
\hline Strain no. & $\begin{array}{l}\text { Starch } \\
\text { peptone }\end{array}$ & $\begin{array}{l}\text { Xylan } \\
\text { peptone }\end{array}$ & $\begin{array}{l}\text { Glycerol } \\
\text { asparginase }\end{array}$ & $\begin{array}{l}\text { Glucose } \\
\text { nitrate agar }\end{array}$ & $\begin{array}{l}\text { Carboxy } \\
\text { methyl } \\
\text { cellulose } \\
\text { peptone } \\
\text { agar }\end{array}$ & $\begin{array}{l}\text { Pectin } \\
\text { peptone } \\
\text { agar }\end{array}$ \\
\hline CSIR-1 & 0 & + & 0 & + & + & + \\
\hline LYCES-13 & 0 & 0 & 0 & + & 0 & + \\
\hline CCES-11 & + & + & + & + & 0 & + \\
\hline WCESP-2 & 0 & 0 & 0 & + & 0 & + \\
\hline WCES-5 & + & + & + & + & 0 & + \\
\hline WCRS & 0 & 0 & 0 & + & 0 & + \\
\hline WSIR & + & + & + & 0 & 0 & 0 \\
\hline CCWSD & + & 0 & 0 & 0 & + & 0 \\
\hline CCLS-18 & + & 0 & 0 & + & 0 & 0 \\
\hline Pseudomonas & + & + & 0 & 0 & + & 0 \\
\hline OCESC-16 & 0 & + & 0 & 0 & 0 & + \\
\hline WCWPS-3 & 0 & 0 & + & 0 & 0 & 0 \\
\hline WCLS & 0 & + & 0 & + & 0 & 0 \\
\hline WWCES-19 & + & 0 & 0 & 0 & + & 0 \\
\hline CCESD-12 & 0 & 0 & 0 & 0 & 0 & 0 \\
\hline CCERD-10 & 0 & 0 & + & 0 & 0 & + \\
\hline RCES-17 & 0 & 0 & 0 & 0 & 0 & 0 \\
\hline CCRS & 0 & + & 0 & + & + & 0 \\
\hline
\end{tabular}

Only one strain WWCES-19 which showed yellow in colour. The strain CCRS showed the watery white colony. The size of the colonies ranges from 1-20 mm in diameter. Maximum colony diameter was showed by CSIR-1 with $20 \mathrm{~mm}$ in diameter. Of these 18 bacterial strains margin appear on entire with lobed. The elevation of the bacterial colonies are maximum convex and flat with smooth and rough surface.
Finally the 10 strains are gram positive and the remaining strains showed gram negative rods. Pseudomonas strain which showed the best colony characters among the strains. Therefore we selected 6 strains for further studies like amino acid infilteration and seasonal effects also. 
Seasonal effect of bacteria associated with Ramie canes

Table -3 represents the 6 bacterial strains were introduced into winter, summer and rainy seasons. The study as conducted in 24, 48 and 72 hours of intervals. Maximum colony growth was observed in $72 \mathrm{~h}$ of incubation with 85.00 average of colony count. The strain CSIR-1 which showed the maximum colony growth in rainy season with 30.0 colony count at $48 \mathrm{~h}$ of incubation. The other strains CCES, Pseudomonas sp. and WCESP showed minimum colony count. Only one strain CILS showed least colony count on three seasons.

Table 3. Seasonal effect of bacteria associated with Ramie canes

\begin{tabular}{|c|c|c|c|c|c|c|c|c|c|}
\hline \multirow[t]{2}{*}{ Strain no } & \multicolumn{3}{|c|}{ Winter } & \multicolumn{3}{|c|}{ Summer } & \multicolumn{3}{|l|}{ Rains } \\
\hline & 24 & 48 & 72 & 24 & 48 & 72 & 24 & 48 & 72 \\
\hline CSIR-1 & 17000 & 21000 & 19000 & 13000 & 10000 & 14000 & 18000 & 30000 & 23000 \\
\hline CILS & 500 & - & - & - & 500 & - & - & 500 & - \\
\hline CCLS & 1000 & 2000 & 85000 & - & 2000 & - & - & 12000 & - \\
\hline CCES & 10000 & 3000 & 12000 & 10000 & - & - & - & 6000 & - \\
\hline P.SP & 17000 & - & 7000 & 2000 & 7000 & 6000 & 5000 & 6000 & 6000 \\
\hline WCESP & 1000 & - & 2000 & 2000 & - & 2000 & 3000 & 4000 & 1000 \\
\hline
\end{tabular}

\section{Effect of amino acid infiltration of bacteria}

Table-4 represents that there are 10 amino acids were studied for this study. Three strains CSIR-1, WCRS and CCLS showed positively reacted on this amino acid infilteration. Majority of the strains showed negative results. These six strains selected for further studies like characterization.

Table -4. Effect of amino acid infiltration of bacteria

\begin{tabular}{|c|c|c|c|c|c|c|c|c|c|c|}
\hline \multirow[t]{2}{*}{ Strain no } & \multicolumn{10}{|c|}{ CMPCA PLATES } \\
\hline & 1 & 2 & 3 & 4 & 5 & 6 & 7 & 8 & 9 & 10 \\
\hline CSIR-1 & + & + & + & - & - & - & - & + & + & - \\
\hline WCES-5 & - & - & - & + & - & - & - & - & - & - \\
\hline CCES-11 & + & - & + & - & - & + & - & - & - & - \\
\hline WCRS & - & - & - & + & - & + & - & - & - & - \\
\hline CCLS & + & - & - & - & + & - & - & + & - & + \\
\hline WCESP & - & - & - & + & - & - & - & - & + & - \\
\hline
\end{tabular}

\section{CONCLUSION}

Ramie canes were used in the process of decorticating and degumming. The bacterial colonies obtained from ramie cane soils showed the best colony characters with maximum colony count on winter season. All the strains showed the maximum positive characteristics on preliminary and biochemical characterizations. 


\section{REFERENCES}

[1]. Alexander (1961). Introduction of soil microbiology. John wiley \& Sons New York.

[2]. Crueger wolf and Anne crueger (1984). Biotechnology: A text book of industrial Microbiology. Science and technology. Inc. Madison.

[3]. Pepple, H.J. and perlimar . D (1979) (eds). Microbial technology, microbial processes. Academic Press . New York.

[4]. Lopez, J.M. and Real, (1984). High temperature composting as a resource recovery system for agro industrial wastes: in biomass utilization (rd. Wilfred A cote ) plenum press, new York.

[5]. Liu F, X Liang, N Zhang, Y Huang and S Zhang (2001). Effect of growth regulators on yield and fibre quality in ramie (Boemherianivea L. Gaud.) China grass Field Crops Res. 69 41-46

[6]. Subandi M (2012). The effect of fertilizers on the growth and the yield of ramie (Boehmeria nivea L. Gaud) Asian J. Agric. Rural Dev. 2 126-135.

[7]. Gruno M, P. Valjamae, G. Pettersson, G. Johansson, (2004). Biotechnology and Bioengineering 86:503-511.

[8]. Narra, M., Dixit, G., Divecha, J., Madamwar, D., \& Shah, A. R. (2012). Production of cellulases by solid state fermentation with Aspergillus terreus and enzymatic hydrolysis of mild alkali-treated rice straw. Bioresource technology, 121, 355-361.

[9]. Ragab, A. M., EL-Gendy, N. S., Farahat, L. A., \& Madian, H. R. (2014). Bioethanol Production from Rice Straw Enzymatically Saccharified by Fungal Isolates, Trichoderma viride F94 and Aspergillus terreus F98. In Soft(Vol. 2014). Scientific Research Publishing.

[10]. Shenef, A., El-Tanash, A., \& Atia, N. (2010). Cellulase production by Aspergillus fumigatus grown on mixed substrate of rice straw and wheat bran. Research Journal of Microbiol, 5(3), 199-211.

[11]. Lindsey (1976). Microbiology of Aerial plant surfaces. Acad. Press. (Eds. C.H. Dickinson and T.F. Preface).

\section{Cite this article as :}

Darsi Phebe Sarah Koti Ratnam, Davala Simon, "Preliminary and Biochemical Characterization of Bacterial Strains Isolated from Ramie Cane Soils", International Journal of Scientific Research in Science and Technology (IJSRST), Online ISSN : 2395-602X, Print ISSN : 2395-6011, Volume 6 Issue 1, pp. 390-395, January-February 2019. Available at doi : https://doi.org/10.32628/IJSRST196148 Journal URL : http://ijsrst.com/IJSRST196148 